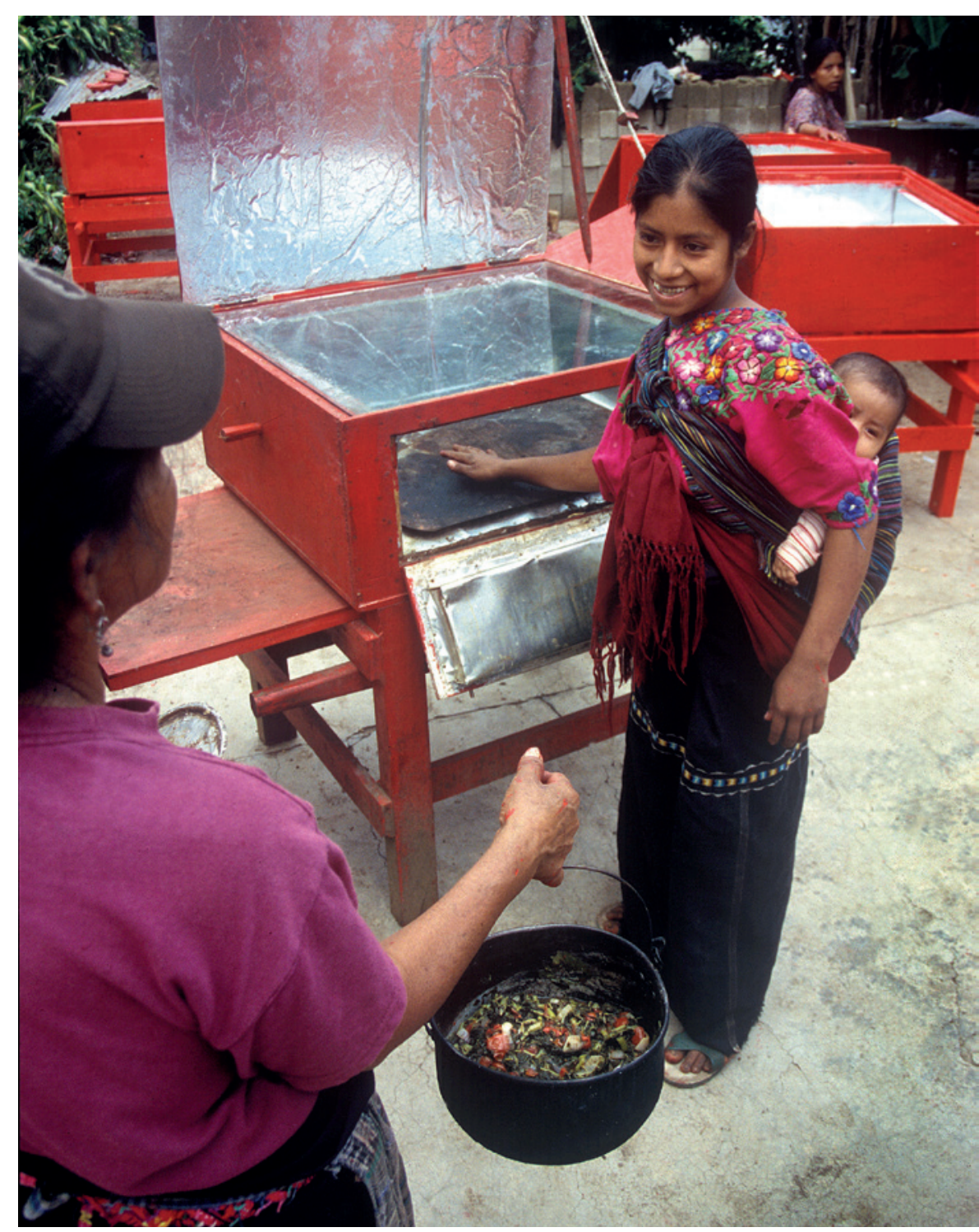

Women in Guatemala cook with a solar oven that they built themselves.

\title{
Clean cooking
}

\section{empowers women}

\section{Putting women and girls at the centre of solar-oven programmes builds communities and reduces pollution, say Laura S. Brown and William F. Lankford.}

A $\mathrm{t} 4$ a.m., Eunice in El Jobo, Nicaragua, puts a fistful of madero de madura (seasoned firewood) in her mud and brick oven. The wood catches flame; a cloud of smoke and ash rises, resting beneath the metal roof. Eunice launches into a coughing fit. Her daily routine has started.

Around the world, 3 billion poor people like Eunice cook over unventilated wood, coal or dung fires. About 4 million deaths a year are associated with inhaling the smoke ${ }^{1}$. Hours spent gathering wood or biomass fuel robs families of time and energy needed for education and work. Deforestation degrades soil and destroys habitats.

Massive efforts are under way to introduce cleaner ways of cooking, such as with solar ovens. Most of these attempts are too narrowly focused. Stoves are replaced without channelling women's time savings and health improvements into community development.

Women who must cook with solid fuels face many other obstacles, such as poor health and malnutrition, lack of transportation, illiteracy, ingrained social attitudes about their roles and potential, and resistance to change from beneficiaries of the status quo.

More-holistic approaches can address a constellation of difficulties, as shown by our long experience with the Central American Solar Energy Project (CASEP, of which W.F.L. is president and L.S.B. is programme coordinator). CASEP is a private foundation funded mainly through family donations. For nearly 25 years, it has provided financial and technical assistance to thousands of poor, rural women for the construction of solar ovens in Guatemala, Costa Rica, Nicaragua and Honduras. CASEP weaves into its programmes opportunities for women to break gender barriers and receive education on health, human rights, leadership and community engagement.

Our modest programme is a worked example of the kind of on-the-ground change that is needed more broadly at the nexus of international development, clean-energy markets and sustainable technologies. We call on decision-makers in these fields to reframe their work around supporting women to adopt clean cooking by following four key practices (see 'Lifting lives, not just swapping stoves'). These steps encourage individual, household and community development while reducing carbon emissions.

\section{WIDER BENEFITS}

Solar-cooking initiatives face challenges. Critics emphasize the difficulty of developing financially sustainable markets for solar ovens. The most durable stoves are expensive and difficult to manoeuvre or repair. Cheap ovens are insubstantial and easily stolen. Solar cookers that are designed to focus the Sun's rays with parabolic mirrors are vulnerable to wind damage and require constant repositioning to catch sunlight. Opportunities for generating profit are limited - no one sells sunshine.

Distributing subsidized solar ovens also has drawbacks. International-development programmes are results-driven and focus on easily measurable impacts. They do not draw connections between women's cooking needs and their other needs. The focus is the stove, not the people who use it.

The most prominent clean-cooking effort is the Global Alliance for Clean Cookstoves. Launched five years ago by then-US secretary of state Hillary Clinton, the alliance counts 1,000 government, non-profit, academic and business groups as partners. Its goal is 
to convert 100 million households to clean cooking fuels by 2020 and to establish a thriving market for clean stoves, with a focus on eight countries: Nigeria, Kenya, Uganda, Ghana, Guatemala, Bangladesh, India and China. Solar power is not a focus: of 278 stove designs promoted, only 13 are sun-powered.

CASEP has a different approach. Zero greenhouse-gas emissions and free fuel make solar ovens the cleanest and most accessible option for many poor households, costing around US\$300 each in materials and workshop costs (see go.nature.com/pvweju).

When CASEP was launched in 1991, local tradesmen built the ovens and presented them to their wives. The women took the gesture as criticism - what was wrong with how they had cooked all those years? The ovens gathered dust. So we put women at the heart of the programme.

\section{KEEPING MOMENTUM}

Today, at solar-cooking demonstrations, we identify 10-20 women who wish to build an oven. We train some as instructors and provide materials. The women invest a lot of work and time, spending up to three full-time weeks or ten weekends working on the stoves.

Women construct them from plywood, glass, aluminium and metal. They use hammers, hand saws, shears and sealant guns — items they had considered 'men's tools'. Participants complete each step of the construction process by rotating among several work stations. Building the ovens collectively and in stages nurtures a spirit of solidarity.

The workshop serves as a proving ground for leadership skills. Participants elect a leadership team to manage the workshop finances, meals and interpersonal issues. Once the ovens are complete, graduates celebrate in public at the clausura, a solar banquet with music and festivities. "This oven that we women have made with our very own hands is a source of pride for me... it's a great advantage," said Maria Francisca, a workshop graduate in Nicaragua. Adequate follow-up is key

\section{"The focus of international- development programmes is the stove, not the people who use it."} to the adoption of solar cooking. Ongoing support is provided for at least two years by CASEP staff in each country.

Women who use solar ovens tell us that they save the time spent on gathering firewood and the money spent on fuel; are able to leave their meals to cook unattended; and enjoy clean indoor air and improved health. And the benefits go further.

Women apply their new skills to advocate for themselves and others. They form solidarity groups, feeding programmes and micro-loan enterprises. They develop

FOUR STEPS TO CLEAN COOKING Lifting lives, not just swapping stoves

1 Develop flexible, integrated, longterm approaches. Poor women and communities face multiple difficulties; it is not possible to fix only one component. The women should be asked: what strengths and challenges do they see in their communities? How would they like to respond? What do they need to realize that response? Monthly visits, consultations and repair assistance should be funded for several years after ovens are introduced ${ }^{3}$.

\section{2} Promote solar ovens worldwide as companions to other clean stoves. Women often persist with solar cooking until their income rises. Then, they opt for the methods of the middle class: stoves powered by natural gas or electricity. Policy-makers should advance and incentivize solar cooking as the cleanest option. Research is needed to establish the effectiveness of solar ovens used in conjunction with improved stoves such as those that use liquified petroleum gas or compressed biomass pellets in reducing carbon emissions and greenhouse gases.

ecological household systems for water and waste, organic community farms and urban agriculture programmes. "They emerge as new women: women without limits, who value themselves, who have rights, who refuse to be limited or violated by anyone," said Fatima, a participant in Costa Rica ${ }^{2}$.

CASEP's affiliate group in Honduras, the Association of Women Defenders of Life, manages a micro-loan programme, leads efforts to prevent maternal and child malnutrition and facilitates leadership and civic-engagement programmes for women and young people.

In Costa Rica, CASEP gave rise to Casa del Sol (House of the Sun), a demonstration centre for household solar applications such as cooking, water purification and lighting. And Sol de Vida (Sun of Life), which constructs solar ovens, works for gender equality and engages in ecological activism.

In Nicaragua, the Solar Project Foundation for Nicaraguan Women won the 2013 Energy Globe World Award in the air category, for its construction of solar ovens in rural and semi-urban communities.

There have been setbacks. Some women's associations have stopped. Ovens have been abandoned. Programmes have ceased owing to corruption and lack of leadership. Finding and retaining skilled female leaders is CASEP's biggest challenge. Many of the programme's beneficiaries become local

Quality standards that better quantify 'clean fuels' should recognize solar cooking as the gold standard.

3 social-science studies are needed to probe the ways in which poor women receive support during the conversion away from their conventional methods of cooking. Researchers should investigate how it affects daily routines, what shapes the ways they invest their new-found time and what cultural factors hinder the conversion to clean cooking fuels.

4 Evaluate the benefits for future generations. Researchers should quantify the effects of cooking with clean stoves on all members of the household, particularly young people. Seeing three girls cooking with their mother's solar oven in Guatemala in 2010 demonstrated to us at CASEP that for the next generation, cooking with solar ovens could be as natural as cooking with wood.

community leaders and advocates; few want to develop the professional skills needed to lead an international organization.

The difficulty of adapting lifestyles to cook with sunlight is also a challenge. Although a CASEP solar oven is simple to repair, long-lasting and large enough to cook a full meal for a typical family, it requires longer cooking times that depend on the weather. Households that use solar cooking need to change how and when they prepare food, and need ongoing support.

Leaders in public policy, sustainable technologies, emerging energy markets and international development should focus on encouraging women to adopt clean cooking practices. Conversion efforts towards cleaner stoves that leverage savings in women's time and resources for the common good will amplify the benefits and create community change.

Laura S. Brown is programme coordinator and William F. Lankford is founder and president of the Central American Solar Energy Project (CASEP), Charlottesville, Virginia, USA.

e-mail:casep12@gmail.com

1. Subramanian, M. Nature 509, 548-551 (2014).

2. Vega, N. M. Sol de Vida y La Red Solar 5-6 (Univ. Costa Rica, 2001).

3. Kammen, D. M. \& Lankford, W. F. Nature 348 385-386 (1990). 